\title{
Pengaruh Etos Pimpinan terhadap Motif Berprestasi Kerja Karyawan
}

\author{
Maman Suherman
}

\begin{abstract}
In order to gain the predicate of Good Corporate Government, some government bureaus have managed to run strategic moves. PT Telkom was among those whose ambitions was to be the best e-government organization. The success of such program was never easy because many factors contributed on such matters. One of crucial factors contributed for the creating a good exemplar of Good Corporate Government is the workforce group, especially on the workers ability for working. To implement a good working performance, PT Telkom created a corporate culture reflected some ideal values, i.e. Cleanliness, Transparency, and Professionalism. It was the role of leaders then to socialize the values. Leaders have responsibilities to motivate workers in his unit. Motivation derived from many sources: given materials, communication activity, financial/material rewards, and so on. This paper examinee how leader's ethos could be very effective in influencing workers motivation. . In order to do so, ethos concept is divided by three aspects: credibility, attraction, and power. Research results show that the influence of leader's credibility toward motivation is insignificant. On the other hand, there is significant relationship between appeals and leader's power toward workers/staff motivation.
\end{abstract}

Kata kunci: etos, motif, karyawan

\section{Pendahuluan}

PT Telkom, yang bervisikan to be a leading infocom company in the region, saat ini memiliki target mencapai Good Corporate Governance yang pada dasarnya adalah suatu kondisi di mana perusahaan dapat memberikan kepuasan kepada stakeholder. Salah satu upaya guna mencapai target ini, manajemen telah mengeluarkan kebijaksanaan Bersih, Transparan, dan Profesional (BTP) sebagai pedoman bagi karyawan dalam bekerja, di samping peraturan yang ada.

Budaya Bersih, Transparan, dan Profesional sebagai pedoman yang berisikan nilai-nilai harus disosialisasikan kepada seluruh karyawan di seluruh lapisan, dipahaminya, dan dilaksanakan. Pemahaman budaya tersebut perlu pula didukung daya dorong (motif) karyawan dalam menjalankan semua tugas yang menjadi tanggung jawabnya. Pemberian motivasi oleh pimpinan tidak selalu berupa pemberian materi. Motivasi dapat dilakukan dengan cara memperhatikan aspek kemanusiaan karyawan dan memberikan informasi yang lengkap tentang kebijaksanaan, tugas, dan informasi lainnya yang perlu diketahui karyawan. Untuk itu, interaksi dan komunikasi antara pimpinan dan karyawan menempati posisi yang strategis dan penting. "Ditinjau dari sudut pandang manajemen, semua tindakan pimpinan harus melewati leher botol komunikasi. Semua gagasan besar 
manajemen hanya merupakan pikiran di belakang meja sampai manajer dapat menerapkannya lewat komunikasi," demikian dikatakan Davis dan Newstron (1993:151).

Fungsi komunikasi bukan hanya untuk menyampaikan informasi semata. Komunikasi, khususnya komunikasi dua arah (dialogis), dapat pula dimanfaatkan untuk mengubah opini, sikap, dan perilaku karyawan. Komunikasi dialogis adalah proses komunikasi yang terjadi antara pimpinan dan karyawan secara timbal balik. Melalui komunikasi dialogis, pimpinan berpeluang memberikan motivasi karyawan karena pimpinan dapat mengetahui apa yang dibutuhkan karyawannya, termasuk kebutuhan akan informasi. Pareek (1996:98) mengatakan "Komunikasi umpan balik itu membantu usaha mengambil langkahlangkah perbaikan dan penyesuian yang diperlukan dan memberikan motivasi kepeda orang-orang yang mengembangkan rencana-rencana menantang dan realistis" Sementara itu, Pekerti (1986:36) berpendapat “Tanpa motivasi, produktivitas kerja sulit tercapai."

Keberhasilan pimpinan dalam memenej nilainilai yang terkandung dalam budaya perusahaan (corporate culture) merupakan refleksi keberhasilannya menjalankan fungsi kepemimpinannya. Gross (1983:192) berpendapat "Kepimimpinan adalah suatu proses mempengaruhi yang dimiliki seseorang terhadap orang lain untuk menggerakan mereka ke arah tujuan yang spesifik." Dalam konteks ini, apabila keberhasilan pimpinan memengaruhi karyawan dilakukan melalui proses komunikasi, berarti pimpinan tresebut berhasil dalam berkomunikasi. Seperti dikatakan Henry Effendy (1992:54) "Kepemimpinan yang efektif berarti komunikasi yang efektif."

Dari sudut pandang komunikator (pimpinan), komunikasi akan efektifjika komunikator dipersepsi komunikan memiliki etos yang terdiri dari kredibilitas, atraksi, dan kekuasaan.

Yang dimaksud pimpinan dalam penelitian ini adalah Assistant vice President atau pejabat setingkat. Sedangkan karyawan adalah para officer yang berada di bawah tanggung jawabnya.

\section{Perumusan}

Berapa besarkah pengaruh Kredibilitas, Atraksi, dan Kekuasaan Assistant Vice President atau Pejabat Setingkat dalam berkomunikasi dengan karyawan terhadap motif berprestasi kerja karyawan. PT Telekomunikasi Indonesia, Tbk. (PT Telkom, Tbk.)

\section{Maksud dan Tujuan Penelitian}

Maksud penelitian ini adalah untuk menguji unsur-unsur etos yang terdiri kredibilitas, atraksi, dan kekuasaan Assistant Vice President atau pejabat setingkat dalam berkomunikasi dengan karyawan terhadap motif berprestasi kerja karyawan PT Telkom Kantor Pusat Bandung.

Penelitian ini bertujuan untuk mengetahui besarnya pengaruh dan mengkaji pengaruh kredibilitas, atraksi, dan kekuasaan Assistant Vice President atau pejabat setigkat dalam berkomunikasi dangan para karyawan terhadap motifberprestasi kerja karyawan PT Telkom Kantor Pusat Bandung.

\section{Landasan Konseptual}

Di dalam perusahaan terlibat karyawan yang bekerja secara terkoordinasi, ada pembagian tugas dan tanggung jawab, ada pimpinan, serta yang dipimpin (karyawan) guna mencapai tujuan tadi. Para karyawan dapat menyelesaikan tugas, kewajiban, dan tanggung jawabnya apabila mereka memiliki informasi yang cukup berkaitan dengan hal-hal tersebut, di samping fasilitas yang memadai.

Memahami peraturan yang berlaku dan pedoman berupa nilai-nilai yang patut untuk ditaati dapat dijadikan landasan bagi para karyawan dalam melaksanakan semua tugasnya tetap berada pada jalur yang benar. Semua informasi perlu disosialisasikan dan dipahami oleh mereka yang terlibat dalam perusahaan, baik pimpinan maupun karyawan.

Pada sisi lain, pimpinan juga harus memperlakukan karyawan sebagai manusia. Aspek manusiawi dari karyawan perlu pula diperhatikan. Dengan demikian, karyawan akan berusaha bekerja 
Terakreditasi Dirjen Dikti SK No. 56/DIKTI/Kep/2005

produktif guna mencapai kinerja yang tinggi dalam rangka mencapai aktualisasi diri. Dikatakan oleh Carl Rogers (dalam Rakhmat, 1985:40) bahwa salah satu pandangan humanisme "Manusia berperilaku untuk mempertahankan, meningkatkan, dan mengaktualisasikan diri." Pandangan ini menggambarkan bahwa karyawan sebagai manusia ingin mencapai suatu tingkatan tertentu dalam hidupnya, yang menurutnya, salah satunya dapat dicapai di tempat kerjanya. Potensi inilah yang patut digali dan dikembangkan oleh pimpinan melalui pemberian motivasi lewat komunikasi dialogis dan tetap memerhatikan aspek manusiawinya.

Teori human relations yang bermuara dari mazhab humanisme, berpandangan bahwa aspek individu dan hubungan sosial merupakan aspek penting dalam perusahaan. Oleh sebab itu, sumber daya manusia yang terlibat di dalam suatu organisasi, khususnya perusahaan, tidak diperlakukan sebagai komoditas ekonomi semata, namun mereka dihargai sebagaimana layaknya manusia. Karyawan merupakan komponen yang sangat penting dalam perusahaan.

Hasil studi Mayo yang dikenal dengan nama studi Hawthorne menunjukkan bahwa penambahan cahaya yang konsisten tidak berpengaruh terhadap penambahan produksi mereka. Peneliti menyadari bahwa penambahan produksi disebabkan oleh keadaan di mana pekerja merasa dirinya diawasi orang lain. Pengaruh peneliti terhadap produksi mulai menunjukkan pengaruh komunikasi manusia terhadap tingkah laku anggota organisasi (Muhammad, 1995:41). Tentang cakupan human reletions, Hisedort (dalam Susanto, 1977:5) mengatakan, hubungan antarmanusia membahas segi-segi bagaimana: “(1) memeroleh kesediaan kerjasama dari orang-orang dengan siapa orang bekerja; (2) memungkinkan orang berproduksi dan berprestasi lebih tinggi; (3) memungkinkan orang bekerja dengan memeroleh kepuasan dari hasilnya."

Pada hakikatnya, aktivitas human relations dalam perusahaan berlangsung melalui proses komunikasi antarpesona secara tatap muka. Proses komunikasi tadi berlangsung secara dialogis. Dalam proses komunikasi dialogis antara pimpinan dan karyawan akan terjadi saling memengaruhi, menghargai apa yang dikatakan mitranya, dan saling menilai. Ada hubungan yang positif antara ketepatan komunikasi yang berkenaan dengan tugas, komunikasi kemanusiaan, dan komunikasi pembaruan dengan kepuasan kerja dan hasil yang dicapai oleh pekerja. Proses komunikasi dialogis antara pimpinan dan karyawan dapat berlangsung secara formal dan informal. Dengan demikian, melalui proses komunikasi, khususnya dialogis, pimpinan dapat berusaha untuk memengaruhi para karyawan agar mereka dalam menyelesaikan tugasnya sesuai dengan yang diharapkan pimpinan, demi tercapainya tujuan perusahaan yang pada gilirannya akan memberikan kesejahteraan dan kepuasan batiniah bagi karyawan. Kalau hal ini tercapai, maka itu berarti komunikasi tadi efektif.

Menurut Devito (1989:96-103), "Dari sudut pandang humanistik, karakteristik efektivitas komunikasi antarpribadi menekankan pada aspek komunikator (pimpinan-pen.), komunikasi akan efektif apabila komunikator memiliki etos yang menurut Rakhmat (1985:263) "Terdiri atas dimensi kredibilitas, atraksi (daya tarik), dan kekuasaan."

Rakhmat (1985:264) menyebutkan bahwa "Kredibilitas adalah seperangkat persepsi komunikate tentang sifat-sifat komunikator." Selanjutnya, Rakhmat menyebutkan bahwa sifatsifat komunikator tadi adalah merupakan komponen-komponen kredibilitas yang meliputi keahlian dan kepercayaan. Komunikator yang dipersepsi memiliki keahlian yang tinggi adalah orang yang cerdas, mampu, ahli, tahu banyak, dan berpengalaman atau terlatih. Sedangkan komunikator yang dipersepsi dapat dipercaya adalah aoang yang dinilai jujur, bermoral baik, adil, dan sopan.

Sejalan dengan pendapat di atas adalah model fungsional kredibilitas yang mengatakan "Semakin terpenuhi suatu kebutuhan komunikan oleh komunikator, semakin dapat dipercaya komunikator itu. Sebagai contoh adalah pemenuhan kebutuhan akan informasi mutakhir oleh komunikator" (Infante, Rance, dan Womack, 1990:175). 
Unsur kedua dari etos adalah atraksi atau daya tarik. Atraksi atau daya tarik adalah persepsi komunikan tentang daya tarik yang dimiliki komunikator ketika komunikasi berlangsung. Menarik atau tidak komunikator ketika berkomunikasi, penilaiannya ada pada komunikan. Calhoun dan Acocella (1990:265) menyebutkan bahwa "Ada lima faktor penentu daya tarik seseorang yaitu: daya tarik fisik, kemampuan, kedekatan, kemiripan, dan keuntungan”.

Unsur ketiga dari etos adalah kekuasaan. "Kekuasaan adalah kemampuan menimbulkan ketundukan," demikian bunyi teori Kelman, seperti dikutip Rakhmat (1985:263). Menurut Kelman, pengaruh sosial yang diakibatkan penggunaan kekuasaan adalah ketundukan yaitu bila individu menerima pengaruh orang lain atau kelompok lain karena ia berharap mendapat reaksi yang menyenangkan dari orang lain atau kelompok tadi.

Dalam sebuah perusahaan, kekuasaan, khususnya kekuasaan legal dimilki oleh orang-orang yang menempati suatu jabatan struktural. Kekuasaan karena jabatan disebut kekuasaan legal. Mereka dapat memberikan perintah karena secara normatif di perusahaan itu dibenarkan.

Raven dalam Rakhmat (1985:274) mengidentifikasi kekuasaan menjadi lima jenis yaitu: kekuasaan koersif, keahlian, informasional, rujukan, dan legal.

Bila seorang piminan dipersepsi oleh karyawan ketika berkomunikasi memiliki kegita unsur etos yaitu: kredibilitas, daya tarik, dan kekuasaan, maka sangat dimungkinkan pesan komunikasinya efektif. Artinya, pesan (informasi) yang disampaikan pimpinan dipahami oleh karyawan sesuai dengan yang dimaksudkan oleh pimpinannya. Jadi, komunikasi yang efektif terjadi jika ada perubahan pada diri penerima pesan (komunikan), baik berkenaan dengan aspek kognisi, afeksi, atau konasi. Dikatakan oleh Effendy (1981:28) bahwa "Komunikasi adalah proses penyampaian lambang-lambang yang berarti oleh seseorang kepada orang lain, baik dengan maksud agar mengerti ataupun agar berubah perilakunya." Dengan demikian, pimpinan dapat memberikan dorongan (motivasi) kepada karyawan lewat upaya komunikasi. Motif yang dimiliki karyawan dapat menentukan produktivitas kerjanya.

"McClelland (dalam Hasibuan, 1994:180) mengutarakan dalam teori "Achievement Motivation Theory" tiga motif atau kebutuhan yang memotivasi seseorang yaitu: Need for Achievement ( $n$ Ach), Need for Affiliation ( $n$ af), dan Need for Power (n pow).

Motif berprestasi adalah dorongan dalam diri orang-orang untuk mengatasi segala tantangan dan hambatan dalam upaya mencapai tujuan (Dharma, 1996:88). Unsur-unsur motif berprestasi yang dikemukakan McClelland (dalam Sukmadinata, 1983:118-119) adalah sebagai berikut: (1) Kebutuhan berprestasi; (2) Keinginan berprestasi; (3) Antisipasi tujuan; (4) Hambatan; (5) Bantuan; (6) Suasana perasaan; (7) Tema berprestasi.

\section{Pembahasan}

Hasil penelitian ini menunjukkan bahwa pimpinan yang dipersepsi memiliki kredibilitas tinggi oleh karyawan (46,51\% karyawan) tatkala berkomunikasi dengan karyawan, tidak berpengaruh secara signifikan terhadap motif berprestasi kerja karyawan. Faktor kredibilitas bukan merupakan faktor yang mampu memberikan dorongan bagi karyawan untuk berprestasi, padahal pimpinan dipersepsi karyawan (yang mayoritas sarjana) memiliki kredibilitas tinggi. Artinya, pimpinan dipersepsi memiliki kemampuan berkomunikasi dan dipandang ahli dalam bidangnya, akan tetapi tidak memberikan dorongan yang berarti bagi karyawan untuk berprestasi. Hasil penelitian ini bertolak belakang dengan riset yang dilakukan Hovland dan Weiss (dalam Applbaum dan Anatol, 1974:68) bahwa "Komunikator yang dipercaya (kredibilitas tinggi) lebih sukses menghasilkan perubahan sikap daripada komunikator yang tidak dapat dipercaya (kredibilitas rendah)."

Perlu disadari bahwa efektivitas komuniksai, tentu saja bukan melulu karena kredibilitas. Bisa jadi, kemampuan pimpinan dalam berkomunikasi dinilai baik, namun dia dipandang kurang mampu memilih kata-kata yang tepat untuk istilah-istilah tertentu yang agak sulit padanannya dalam bahasa 
Terakreditasi Dirjen Dikti SK No. 56/DIKTI/Kep/2005

Indonesia, terutama istilah-istilah yang sangat spesifik (memiliki tingkat abstraksi tinggi). Bila hal ini terjadi, maka akan sulit bagi karyawan untuk memahami makna sesungguhnya. Ketidakpahaman ini bisa berakibat terlambatnya penyelesaian tugas-tugas tertentu. Fiedler (dalam Koontz, dkk., 1996:159) mengatakan “Apabila tugas jelas, kualitas prestasi dapat dikendalikan dengan mudah, dan anggota kelompok dapat lebih pasti memikul tanggung jawab untuk berprestasi dibandingkan dengan apabila tugas tidak jelas." Terpenuhinya kebutuhan informasi pada diri karyawan dapat meningkatkan kepercayaannya kepada pimpinannya. Model fungsional kredibilitas mengatakan bahwa semakin terpenuhi suatu kebutuhan komunikan oleh komunikator, semakin dapat dipercaya komunikator itu. Sebagai contoh adalah pemenuhan kebutuhan akan informasi mutakhir oleh komunikator (Infante, Rance, Womack, 1990:175).

Dalam kaitan kemampuan memilih kata-kata, teori General Semantics yang menelaah bagaimana berbicara cermat, bagaimana mencocokkan kata dengan kenyataan (keadaan sebenarnya), bagaimana menghilangkan kebiasaan berbahasa yang menyebabkan kerancuan dan kesalahpahaman, mengingatkan komunikator agar berhati-hati dengan abstraksi. Semakin tinggi tingkat abstraksi, makin sukar kata itu diverifikasi dalam kenyataan, dan makin ambigu makna kata itu (Rakhmat, 1985:295).

Pada sisi lain, hasil riset peneliti mendukung beberapa penelitian sejenis. Kurniadi (2000:91) menyimpulkan "Kredibilitas ayah tidak memberikan pengaruh secara signifikan terhadap prestasi belajar anak." Sementara itu, Infante, Rance, dan Womack (1990:174) menyimpulkan hasil risetnya, "Beberapa penelitian menemukan bahwa kredibilitas sumber dapat membujuk orang, sedangkan penelitian lain menunjukkan bahwa tidak ada hubungan antara perubahan sikap dan kredibilitas sumber."

Pengujian hipotesis kedua yaitu daya tarik. Dari lima aspek daya tarik yaitu: (1) daya tarik fisik, (2) kesamaan, (3) ganjaran, (4) kemampuan, dan (5) kedekatan, hanya tiga aspek (daya tarik fisik, kesamaan, dan kemampuan) yang memiliki pengaruh terhadap motif berprestasi kerja karyawan.

Daya tarik fisik pimpinan tatkala berkomunikasi dengan karyawan ternyata mampu memberikan pengaruh terhadap motif berprestasi kerja karyawan. Daya tarik fisik, misalnya pakaian. Pada umumnya, para pimpinan di PT Telkom memakai pakaian yang rapih, bersih, dan berdasi (pada umumnya). Keadaan seperti ini tentu saja dapat diperoleh karena tingkat kesejahteraan mereka. Kesejahteraan tersebut tidak bisa lepas dari jabatan yang diembannya, dan tentu saja, jabatan struktural tersebut diraih karena prestasi. Tampilan secara fisik seperti itu, bagi karyawan secara normal tentu menarik. Oleh sebab itu, hasil riset ini merupakan sesuatu yang wajar. Hasil riset ini sejalan dengan riset Berscheid dan Walster (dalam Calhoun dan Acocella, 1990:267) "Kecantikan dan kegantengan memiliki pengaruh lebih besar pada kesan pertama daripada kekuataan kesan berikutnya." Penelitian lain menyebutkan "Penilaian orang dewasa terhadap orang dewasa lain mengikuti pola yang sama. Orang yang menarik secara fisik dinilai lebih kuat, lebih peka, lebih sopan, lebih mudah bergaul, lebih tenang, lebih menarik dan lebih menggairahkan daripada orangorang yang kurang menarik" (Dion, dkk., Barnes dan Rosenthal, dalam Calhoun dan Acocella, 1990:266).

Dalam aspek daya tarik kedekatan, hasil riset ini tidak mendukung penelitian yang dilakukan Moreland dan Zojone (dalam Calhoun dan Acocella, 1990:268) yang menyimpulkan "Semakin dekat ia bertempat tinggal, semakin sering Anda menjumpainya. Semakin sering Anda menjumpainya, semakin Anda menyukainya." Seringnya orang-orang berinteraksi, semakin terbuka peluang berkomunikasi dan saling mengenal satu dengan lainnya. Begitu pula interaksi antara pimpinan dan karyawannya (stafnya), sangat berpeluang bagi mereka untuk berkomunikasi.

Perusahaan telah menempatkan karyawan secara berdekatan di ruang kerja, pimpinan juga dalam ruangan kerja yang sama. Dalam perilaku 
kedinasan, yaitu ketika memberikan tugas, pimpinan sering pula mendatangi karyawannya, hal ini dimaksudkan untuk menghilangkan kesan birokrasi yang berlebihan. Perilaku semacam ini merupakan refleksi dari perhatian pimpinan kepada karyawannya. Pada sisi lain, karyawan merasa terhormat di mata pimpinan. Upaya mendekatkan diri dengan pihak luar (pipinan kepada karyawan) dapat dilakukan dengan memanfaatkan waktuwaktu luang di kantor, sehingga tercipta suasana informal dalam proses komunikasi antara pimpinan dan karyawan. Kedekatan dapat menghilangkan hambatan psikologis dan sosiologis antara pimpinan dan karyawan di kantor. Dengan demikian, diharapkan iklim kerja yang kondusif dapat tercipta dan kerjasama mereka dapat terjalin dengan baik. Hal ini sesuai dengan salah satu harapan human relations yaitu memeroleh kesediaan kerjasama dari orang-orang dengan siapa orang bekerja. Namun, ternyata kedekatkan tadi tidak ada pengaruhnya terhadap motif berprestasi kerja karyawan.

Dimensi ganjaran sebagai aspek lain dari daya tarik, ternyata tidak berpengaruh terhadap motif berprestasi kerja karyawan. Hasil riset ini memberikan gambaran bahwa upaya karyawan mencapai produktivitas dan berprestasi, tidak didorong oleh adanya ganjaran yang akan diberikan perusahaan/pimpinan. Tampaknya para karyawan paham bahwa ganjaran (reward) akan mereka peroleh dengan menunjukkan kinerja yang tinggi. Pada buku "Pola Karir Pegawai PT Telkom" pasal 56 ayat (1) disebutkan "Promosi ke setiap jenjang karir yang lebih tinggi pada jalur spesialis/ manajerial bukanlah hak pegawai, melainkan merupakan penghargaan dari perusahaan kepada pegawai yang memenuhi persyaratan sesuai dengan ketentuan yang berlaku." Jadi, ganjaran yang mungkin ditampilkan pimpinan kepada karyawan dipahami karyawan bahwa hal itu bukan datang dari pimpinan, melainkan dari perusahaan. Pimpinan dalam kasus ini (pemberian penghargaan) hanya bersifat perantara saja yaitu orang yang memberikan rekomendasi untuk promosi.

Hasil riset ini tidak memberikan dukungan terhadap riset yang dilakukan Heilman dan Gamer (dalam Rakhmat, 1985:275) yang menyimpulkan "Komunikasi akan lebih baik diyakinkan untuk melakukan sesuatu yang tidak disukainya dengan dijanjikan ganjaran daripada ancaman dengan sanksi." Bila memerhatikan penilaian responden terhadap ganjaran cukup tinggi. Akan tetapi, hal ini tidak menjadikan sebagai aspek yang mendorongnya untuk berprestasi.

Pada aspek kesamaan penelitian ini mendukung hasil riset Byrne dan Wong, Rokeach, Moss dan Andrasik, yang menyimpulkan "Orang kulit putih lebih suka bergaul dengan orang kulit hitam yang mempunyai kesamaan sikap dengan mereka daripada orang kulit putih yang mempunyai sikap berlawanan." Penelitian Stotland dan Dunn; Stotland, Zander, dan Natsoulas (dalam Rakhmat, 1985:262) membuktikan bahwa orang mudah berempati dan merasakan perasaan orang lain yang dipandang sama dengan mereka. Begitu pula kesimpulan riset Stotland dan Patchman (dalam Rakhmat, 1985:262) "Kesamaan antara komunikator dan komunikate memudahkan terjadinya perubahan pendapat." Semua riset ini bisa dikatakan dapat memperkokoh teori homophily dan heterophily yang dikemukakan Rogers.

Dalam komunikasi antarpribadi perspektif humanistik yang dialogis, unsur kesamaan merupakan salah satu karakteristik yang perlu dicapai guna mencapai efektivitas komunikasi. Dengan memanfaatkan komunikasi dialogis, pimpinan dapat berupaya membangun kesamaan pemahaman terhadap tujuan perusahaan yaitu Good Corpoarate Governance. Semakin banyak kesamaan antara pimpinan dengan karyawan, khususnya kesamaan dalam memahami dan menjalankan visi dan misi perusahaan, semakin memudahkan mereka memberikan makna terhadap suatu informasi atau masalah yang dihadapi, dengan demikian akan semakin memudahkan mereka mencari solusinya.

Dimensi kemampuan berpengaruh terhadap motif berprestasi kerja karyawan. Hasil ini sejalan dengan kesimpulan riset Aronson (dalam Rakhmat, 1985:145) "Orang yang paling disenangi adalah orang memiliki kemampuan tinggi tetapi 
Terakreditasi Dirjen Dikti SK No. 56/DIKTI/Kep/2005

menunjukkan beberapa kelemahan." Maknanya, bahwa pimpinan hendaknya menyadari bahwa pada dirinya juga ada kelemahan atau kekurangan, selain kemampuan yang dimiliki sebagai kelebihan. Kelemahan atau kekurangan ini justru dapat diatasi pimpinan bilamana dia membuka komunikasi dialogis dengan para karyawannya. Pada komunikasi dialogis, kedua belah pihak dapat saling bertukar informasi. Dengan adanya informasi dari karyawan (misalnya berupa laporan kerja), pimpinan dapat mengetahui efektivitas komunikasi yang dia lakukan terhadap karyawannya.

Merujuk pada hasil riset berkaitan dengan aspek daya tarik (fisik, kesamaan karakteristik, dan kemampuan) yang berpengaruh terhadap motif berprestasi karyawan, para pimpinan dapat memanfaatkan dimensi-dimensi tersebut guna mencapai efektivitas komunikasi yang tinggi. Artinya, pemahaman dan penerimaan atas informasi tertentu akan tinggi, yang pada gilirannya bisa menghasilkan perilaku pada karyawan yang sesuai dengan keinginan pimpinan.

Hipotesis ketiga yaitu pengaruh kekuasaan pimpinan terhadap motif berprestasi kerja karyawan, teruji secara signifikan. Artinya, ada pengaruh yang signifikan kekuasaan yang dimiliki pimpinan terhadap motif berprestasi karyawan.

Aspek kekuasaan dalam riset ini terdiri atas lima dimensi yaitu: (1) kekuasaan koersif; (2) rujukan; (3) informasional; (4) keahlian; (5) legal.

Pada dimensi kekuasaan koersif yang dimiliki pimpinan berpengaruh terhadap motif berprestasi kerja karyawan. Kekuasaan koersif efektif apabila seseorang mampu memengaruhi orang lain untuk melaksanakan apa yang diinginkan karena adanya ganjaran, atau mampu memaksa orang lain tadi melakukan sesuatu karena adanya sanksi. Pengujjian pengaruh aspek kekuasaan koersifyang dimiliki pimpinan terhadap motif berprestasi kerja karyawan, tidak dibedakan pada sisi ganjaran atau sanksi. Kalau kita kembali pada pasal 56 ayat (1) seperti telah disebutkan di atas, pimpinan bisa memberikan rekomendasi (ganjaran) promosi kepada karyawan atau tidak memberikan rekomendasi (sanksi). Apabila dapat dimaknai seperti ini, maka wajar jika kekuasaan koersif yang dimiliki pimpinan dapat memengaruhi motif berprestasi kerja karyawan.

Para pimpinan PT Telekomunikasi Indonesia Tbk., dinilai oleh para karyawannya dapat dijadikan rujukan dalam berperilaku. Para karyawan memersepsi pimpinannya memiliki kekuasaan rujukan yang cukup tinggi. Akan tetapi, hal ini tidak memotivasi mereka untuk berprestasi. Hasil riset ini berbeda dengan temuan Kipnis (dalam Applbaum dan Anatol, 1974:84) "Ketika seorang pimpinan menawarkan ganjaran dan berpartisipasi dalam kelompok, dia lebih menimbulkan perubahan sikap daripada ketika dia tidak berpartisipasi atau ketika dia menggunakan sanksi sebagai dasar kekuasaan."

Pengujian dimensi kekuasaan informasional yang dimiliki pimpinan terhadap motif berprestasi kerja karyawan tidak berpengaruh secara signifikan. Kepemilikan kekuasaan informasional oleh pimpinan berarti bahwa pimpinan dipersepsi memiliki informasi mutakhir berkenaan tentang perusahaan, baik menyangkut kebijakan, maupun perkembangan perusahaan. Persepsi karyawan terhadap dimensi ini cukup tinggi. Akan tetapi, tidak berpengaruh secara signifikan terhadap motif berprestasi kerja karyawan. Hal ini bisa terjadi karena dua hal: (1) para karyawan telah mengetahui informasi berkenaan dengan kebijakan atau perkembangan perusahaan dari sumber lain yang secara sosiologis atau psikologis memiliki kedekatan dengan mereka (biasanya komunikasi bersifat informal). Seperti diungkapkan hasil riset Tompkin (dalam Muhammad, 1995:112) "Sumbersumber informasi yang terbaik adalah orang yang terdekat dengan para karyawan dan yang paling buruk adalah orang yang paling jauh dengan mereka." (2) Para karyawan telah mengetahui informasi-informasi tersebut dari media intern perusahaan, sehingga informasi yang disampaikan pimpinan dinilai terlambat, apalagi jika informasi tersebut baru disampaikan jika pimpinan melihat adanya masalah yang dihadapi para karyawan berkenaan dengan kinerjanya.

Kipnis (dalam Rakhmat, 1985:275) menyimpulkan hasil riset "Kekuasaan informasional seringkali digunakan bila 
komunikator memandang prestasi komunikate yang kurang baik disebabkan oleh kurangnya motivasi." Sementara penelitian Skinner menunjukkan "Berguna dan motivatif memberikan informasi selengkapnya tentang masalah-masalah perusahaan, khususnya informasi-informasi yang melibatkan para pegawai" (dalam Koontz, dkk., 1996:131). Dengan demikian, bukan hanya sisi kemutakhiran informasi yang perlu disampaikan pimpinan kepada para karyawannya, namun faktor kesegeraan untuk menyampaikannya juga hendaknya diperhatikan.

Pengujian dimensi kekuasaan keahlian pimpinan terhadap motif berprestasi kerja karyawan menunjukkan pengaruh yang signifikan. Kekuasaan keahlian dimaksudkan adalah kemampuan pimpinan menundukkan para karyawan untuk melakukan sesuatu dengan keahlian yang dimilikinya. Kekuasaan jenis ini pada umumnya dimanfaatkan pimpinan manakala dia menilai kinerja karyawannya kurang memuaskan. Kekuasaan semacam ini bermanfaat guna mengoreksi dan mengevaluasi kinerja karyawan. Muhammad (1995:181) menyebutkan bahwa beberapa hasil penelitian yang berkaitan dengan kekuasaan keahlian menunjukkan bahwa supervisor akan berkurang pengaruhnya pada bawahannya apabila dia menunjukkan tanda kurang mampu dalam bidangnya." Penelitian lain yang dilakukan Kipnis (dalam Rakhmat, 1985:275) menyimpulkan "Bila atasan melihata bahwa prestasi kerja jelek bawahannya disebabkan kekurangmampuannya, ia akan menggunakan kekuasaan keahliannya." Jelas, bahwa bantuan pimpinan guna mengoreksi kinerja karyawan dapat membantu karyawan tersebut menjadi lebih baik di masa mendatang.

Dimensi kekuasaan legal berpengaruh secara signifikan terhadap motif berprestasi kerja karyawan. Kekuasaan legal dimiliki seseorang karena adanya seperangkat peraturan dalam perusahaan yang menyebabkan dia memiliki kewenangan untuk melakukan suatu tindakan tertentu. Kekuasaan legal berarti kekuasaan yang dimiliki secara de jure. Semakin tinggi jabatan seseorang secara struktural dalam perusahaan, semakin besar kewenangan yang dimilikinya, termasuk berbagai fasilitasnya. Konsekuensinya adalah semakin besar pula tanggung jawabnya. Dengan kekuasaan legal, pimpinan dapat memberikan instruksi sebatas kewenangan yang diberikan kepadanya. Sebaliknya, bawahan harus taat menjalankannya. Muhammad (1995:180) mengatakan "Kekuasaan secara hukum berhasil bila seorang bawahan dengan kebajikan mengambil posisi pada suatu organisasi, setuju untuk menerima instruksi dari atasan.” Jadi, penerimaan suatu perintah dari atasan oleh karyawan bukan karena adanya unsur keterpaksaan pada diri karyawan, melainkan karena dilandasi pemikiran yang baik dan kesadaran yang tinggi karyawan bahwa pimpinannya memang berhak untuk memberikan instruksi tersebut.

\section{Penutup}

(1) Kredibilitas pimpinan, dalam hal ini Assistant Vice President atau pejabat setingkat (pimpinan), dalam komunikasi dialogis dengan karyawan, berpengaruh tidak signifikan terhadap motif berprestasi kerja karyawan PT Telekkomunikasi Indonesia Tbk.

(2) Atraksi atau Daya Tarik Assistant Vice President atau pejabat setingkat (pimpinan) ketika berkomunikasi dialogis dengan karyawan berpengaruh secara signifikan terhadap motif berprestasi kerja karyawan PT Telekomunikasi Indonesia Tbk.

(3) Kekuasaan Assistant Vice President atau pejabat setingkat (pimpinan) yang dipersepsi karyawan berpengaruh terhadap motif berprestasi kerja karyawan PT Telekomunikasi Indonesia Tbk.

\section{Daftar Pustaka}

Al-Rasyid, Harun. 1988. Teknik Sampling, Lembaga Penelitian dan Pengabdian Kepada Masyarakat (LPPM-IKOPIN). Bandung. 
Applbaum, Ronald L. Dan Karl W.E. Anatol. 1974. Strategy for Persuasive Communication, Columbia, Ohio: Charles E. Merrill Publishing Company.

Calhoun, James F. Dan Joan Ross Acocella. 1990. Psychology of Adjustment And Human Relationship. Terjemahan R.S. Satmoko. 1995. Edisi ketiga, Semarang: IKIP Semarang Press.

Davis, Keith dan John W. Newstrom. 1985. Human Behaviour at Work: Organizational Behaviour. Terjemahan Agus Dharma. 1993. Perilaku dalam Organisasi. Edisi ketujuh. Jilid 2. Jakarta: Erlangga.

Devito, Joseph A. 1989. The Interpersonal Communication Book. New York: Harper and Row Publisher.

Dwivedi, R.S. 1979. Human Relations and Organizational Behaviour. New Delhi: Mohan Primlani.

Effendy, Onong Uchjana. 1984. Human Relations dan Public Relations dalam Management. Bandung: Alumni.

1992. Kepemimpinan dan Komunikasi. Bandung: Mandar Maju.

Gobel, Frank G. 1971. The Third Force, The Psychology of Abraham Maslow. Terjemahan A. Supratinya. 1987. Mazhab Ketiga Psikologi Humannistik Abraham Maslow. Yogyakarta: Kanisius.

Goss, Blaine. 1983. Communication In Everyday Life. Belmont: Wadsworth.

Haris, Nasruddin, dkk. 1997. Telekomunikasi Indonesia: Sejarah, Perkembangan dan Proyeksi ke Depan. Bandung: PT Telkom dan Yayasan Ikatan Alumni Lemhanas.

Halloran, Jack. 1978. Applied Human Relations an Organizational Approach. New Delhi: Printice-Hall of India.
Higgins, James M. 1982. Human Relations Concept and Skill. New York: Random House.

Koontz, Harold, Cyril O’Donnell, Heinz Weihrich. 1984. Management. Terjemahan Antarikso, dkk. 1996. Jakarta: Erlangga.

Kurniadi, Oji. 2000. Pengaruh Komunikasi Keluarga Terhadap Prestasi Belajar Anak SMU Negeri di Kotamadya Bandung. Tesis Magister Sains, Program Pascasarjana Universitas Padjadjaran Bandung.

Liliweri, Alo. 1994. Perspektif Teoritis Komunikasi Antarpribadi: Suatu Pendekatan ke Arah Psikologi Sosial Komunikasi. Bandung: Citra Aditya Bakti.

1997. Komunikasi Antarpribadi. Bandung: Citra Aditya Bakti.

McClelland, David C. 1961. The Achieving Society. Terjemahan Siswo Suyanto dan Wihelmus W. Bakowatun. Memicu Masyarakat Berprestasi. Jakarta: Intermedia.

Muhammad, Arni. 1995. Komunikasi Organisasi. Jakarta: Bumi Aksara.

Pace, R. Wayne. 1983. Organizational Communication: Foundation for Human Resource Development. New Jersey: Printice-Hall.

Pace, R. Wayne, Don F. Faules. 1993. Komunikasi Organisasi: Strategi Meningkatkan Kinerja Perusahaan. Terjemahan Deddy Mulyana, Engkus Kuswarno, dan Gembirasari, 1998. Bandung: Remaja Rosdakarya.

Rakhmat, Jalaluddin. 1985. Psikologi Komunikasi. Bandung: Remadja Karya. 1989. Metode Penelitian Komunikasi. Bandung: Remadja Karya.

Sukmadinata, Nana Syaodih. 1983. Kontribusi Konsep Mengajar dan Motif Berprestasi terhadap Proses Mengajar dan Hasil Belajar. Disertasi, Pascasarjana IKIP Bandung. 
